\title{
ADSORPSI $\beta$-KAROTEN YANG TERKANDUNG DALAM MINYAK KELAPA SAWIT (CRUDE PALM OIL) MENGGUNAKAN KARBON AKTIF
}

\author{
Irvan, Olyvia Putri Wardhani*, Nurul Aini, Iriany \\ Departemen Teknik Kimia, Fakultas Teknik, Universitas Sumatera Utara, \\ Jl. Almamater Kampus USU, Medan 20155, Indonesia \\ *Email : olyviapewe@yahoo.co.id
}

\begin{abstract}
Abstrak
Minyak kelapa sawit mentah (CPO) adalah sumber alami terkaya karotenoid, yang memberikan warna oranye-merah pada minyak sawit mentah. Warna pada minyak kelapa sawit yang belum diolah tidak disukai oleh konsumen. Penelitian ini bertujuan untuk mengadsorpsi $\beta$-karoten dari CPO menggunakan karbon aktif, sehingga diperoleh data kinetika, isoterm adsorpsi dan termodinamika adsorpsi. Bahan utama yang digunakan adalah CPO dan karbon aktif. Parameter yang diamati adalah konsentrasi akhir dan jumlah $\beta$-karoten yang dijerap oleh karbon aktif. Proses adsorpsi dilakukan dengan mencampur adsorben ke dalam CPO dengan variasi adsorben : CPO $(\mathrm{w} / \mathrm{w})=1: 3 ; 1: 4 ; 1: 5$ dan $1: 6$ dengan kecepatan pengaduk $120 \mathrm{rpm}$, dan variasi temperatur 40,50 dan $60^{\circ} \mathrm{C}$. Campuran $\mathrm{CPO}$ dan karbon aktif diambil pada selang interval waktu 2 menit hingga mencapai waktu setimbang. Konsentrasi akhir $\beta$ karoten dianalisa menggunakan spektrofotometer UV-Vis. Hasil penelitian memperlihatkan semakin besar jumlah massa CPO maka persentase adsorpsi semakin menurun. Semakin besar temperatur adsorpsi maka persentase adsorpsi semakin meningkat. Selain itu, diperoleh nilai persentase adsorpsi paling maksimum adalah sebesar 95,108\% pada perbandingan 1:3 dan $\mathrm{T}=60{ }^{\circ} \mathrm{C}$. Model kinetika adsorpsi yang mewakili penjerapan $\beta$-karoten yaitu model kinetika orde dua dengan nilai koefisien korelasi sebesar 0,998. Model isoterm adsorpsi yang mewakili dalam penjerapan $\beta$-karoten yaitu model Langmuir dengan nilai koefisien korelasi sebesar 0,959 pada $\mathrm{T}=60^{\circ} \mathrm{C}$. Nilai energy bebas Gibbs $(\Delta \mathrm{G})$ pada masing-masing temperatur sebesar $-24.482,484 ;-24.708,059$ dan $-24.933,634 \mathrm{~J} / \mathrm{mol}$. Nilai perubahan entropi $(\Delta \mathrm{S})$ sebesar 22,557 J/mol K dan nilai perubahan entalpi $(\Delta \mathrm{H})$ sebesar $-17.421,987 \mathrm{~J} / \mathrm{mol}$.
\end{abstract}

Kata kunci : adsorpsi , $\beta$ - karoten, karbon aktif, kinetika, Langmuir.

\begin{abstract}
Crude palm oil (CPO) is the richest natural source of carotenoids which gives the reddish-orange color in crude palm oil. The reddish color in unprocessed palm oil is disliked by consumer. This research is aimed to adsorb the $\beta$-carotene from the CPO using activated carbon, then the kinetics, isotherm models and thermodynamics data of the adsorption process were obtained. The main materials used in this research were CPO and activated carbon. The observed parameters were final concentration and the amounts of adsorbed $\beta$-carotene in activated carbon. The adsorption process was conducted by mixing the adsorbent with $\mathrm{CPO}$ with the variation of adsorbent: $\mathrm{CPO}(\mathrm{w} / \mathrm{w})$ ratio $=1: 3 ; 1: 4 ; 1: 5$ and $1: 6$ with mixing speed $120 \mathrm{rpm}$ and the temperature of 40,50 and $60{ }^{\circ} \mathrm{C}$. The sample of CPO and activated carbon was analyzed at every 2 minutes until the equilibrium was achieved. The final concentration of the unadsorbed $\beta$-carotene was analyzed using UV-Vis spectrophotometer. The results showed that the more $\mathrm{CPO}$ used in the process, the lower the adsorption percentage. The higher the adsorption temperature, the higher adsorption percentage. Moreover, the maximum adsorption percentage was $95.108 \%$ obtained at ratio $1: 3$ and $\mathrm{T}=60{ }^{\circ} \mathrm{C}$. The adsorption isotherm model which fit with the $\beta$-carotene adsorption at $\mathrm{T}=$ $60{ }^{\circ} \mathrm{C}$ was Langmuir model with the correlation coefficient of 0.959 . The adsorption kinetics model which fit with the $\beta$-carotene adsorption was the second order kinetics model with the correlation coefficient of 0.998. The value of free energy Gibbs $(\Delta \mathrm{G})=-24,482.484 ;-24,708.059$ and $-24,933.634 \mathrm{~J} / \mathrm{mol}$ for each temperature respectively, value of entropy changes $(\Delta \mathrm{S})=22.557 \mathrm{~J} / \mathrm{mol} \mathrm{K}$, and value of enthalpy changes $(\Delta \mathrm{H})=-17,421.987 \mathrm{~J} / \mathrm{mol}$.
\end{abstract}

Keywords : adsorption, $\beta$-carotene, activated carbon, kinetics, Langmuir

\author{
Pendahuluan \\ Minyak kelapa sawit mentah (CPO) \\ merupakan sumber karotenoid alami terkaya di \\ dunia dalam bentuk retinol (pro-vitamin A). \\ Karotenoid yang terkandung sekitar 15 sampai \\ 300 kali lebih banyak dibanding yang terdapat \\ pada wortel dan sayuran berdaun hijau, yang \\ memiliki jumlah signifikan pro-vitamin A [18].
}

Selain karotenoid, terdapat pula komponen minor dalam minyak sawit mentah yaitu tokoferol, tokotrienol, sterol, fosfolipid, squalen, dan tripterpenik dan hidrokarbon alifatik. Karotenoid memberikan warna oranye-merah pada karakteristik minyak mentah kelapa sawit. $\alpha$ - dan $\beta$-karoten, memiliki kadar vitamin A yang dapat diubah menjadi vitamin A in vivo [15]. 
Menurut Standar Malaysia, warna minyak sawit mentah harus terang, jelas dan oranyemerah [11]. Berbagai metode pengambilan karotenoid dari minyak kelapa telah dilakukan. Termasuk saponifikasi, proses adsorpsi, ekstraksi pelarut selektif, dan proses transesterifikasi yang diikuti oleh distilasi [1]. Beberapa penelitian telah dilakukan untuk mengambil $\beta$-karoten dari minyak kelapa sawit menggunakan bleaching earth yang telah diaktivasi [19]. Penelitian yang mengkaji mekanisme penghilangan warna dari minyak nabati dengan proses adsorpsi $\beta$-karoten menggunakan asam sepiolit yang telah diaktivasi [7] dan penelitian yang mengkaji kinetika penyerapan pigmen $\beta$-karoten dari minyak sawit menggunakan tanah liat alami yang dimodifikasi [6]. Penelitian ini bertujuan untuk mengambil $\beta$ karoten dari minyak kelapa sawit dengan proses adsorpsi menggunakan karbon aktif, selain itu untuk mendapatkan model kinetika, isotherm dan termodinamika adsorpsi.

\section{Teori}

Buah kelapa sawit menghasilkan tiga jenis minyak dengan warna yang berbeda, yaitu oranye-merah adalah minyak sawit mentah yang diekstrak dari mesocarp, warna kuning adalah minyak inti sawit mentah dan warna kecoklatan yang diekstrak dari biji (kernel). Minyak sawit mentah adalah sumber alami terkaya karotenoid dan tokotrienol. Karotenoid (500-700 ppm) memberikan warna oranye-merah pada karakteristik minyak sawit mentah (CPO) [16]. Tabel 1 memperlihatkan sifat fisik $\beta$-karoten.

Tabel 1. Sifat Fisik $\beta$-Karoten $[21,2]$

\begin{tabular}{|l|c|}
\hline \multicolumn{2}{|c|}{ Spesifikasi } \\
\hline Berat Molekul & $536,8 \mathrm{~kg} / \mathrm{kmol}$ \\
\hline Densitas $\left(20^{\circ} \mathrm{C}\right)$ & $1000,15 \mathrm{~kg} / \mathrm{m}^{3}$ \\
\hline Tekanan Uap $\left(70^{\circ} \mathrm{C}\right)$ & $3 \times 10^{-6} \mathrm{kPa}$ \\
\hline Warna & Oranye \\
\hline
\end{tabular}

Zat warna $\beta$-karoten mempunyai rumus kimia $\mathrm{C}_{40} \mathrm{H}_{56}$, yang membentuk persenyawaan simetris. Di bagian tengah senyawa tersebut merupakan rantai atom $\mathrm{C}$ yang panjang dengan ikatan-ikatan rangkap yang dapat ditukar dengan ikatan tunggal. Pada kedua ujung rantai ini terdapat cincin segi enam [4]. Struktur $\beta$-karoten disajikan pada Gambar 1.

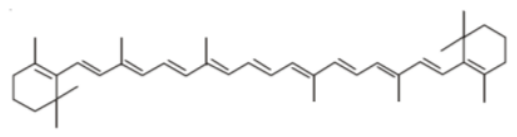

\section{Gambar 1. Struktur $\beta$-Karoten [10]}

Karbon aktif adalah bentuk karbon yang telah diproses untuk dibuat sangat berpori sehingga memiliki luas permukaan yang sangat besar.
Dalam 1 gram karbon aktif memiliki luas permukaan lebih dari $500 \mathrm{~m}^{2}$. Karbon aktif dapat dibuat dari bahan bersumber karbon seperti tempurung kelapa, gambut, kayu, sabut, dan batubara [17]. Karbon aktif memiliki struktur amorf hidrofilik, dengan diameter pori rata - rata $1-4 \mathrm{~nm}$, porositas partikel $40-85 \%$, luas permukaan $300-2000 \mathrm{~m}^{2} / \mathrm{gr}$, kemampuan adsorpsi $0,3-0,7 \mathrm{~kg} / \mathrm{kg}$ kering [1,9]. Tabel 2 menunjukkan sifat fisika dan sifat kimia karbon aktif.

Tabel 2. Sifat Fisika dan Sifat Kimia Karbon Aktif [13]

\begin{tabular}{|l|c|}
\hline \multicolumn{2}{|c|}{$\begin{array}{c}\text { Sifat Fisika dan Sifat Kimia Karbon } \\
\text { Aktif }\end{array}$} \\
\hline Bentuk & Padatan \\
\hline Ukuran Partikel & $<100 \mu \mathrm{m}$ \\
\hline Titik Didih & $4.000^{\circ} \mathrm{C}$ \\
\hline Titik Leleh & $3.500^{\circ} \mathrm{C}$ \\
\hline Berat Molekul & $12,011 \mathrm{~g} / \mathrm{mol}$ \\
\hline
\end{tabular}

\section{Metodologi Penelitian}

Bahan-bahan yang digunakan dalam penelitian ini adalah minyak kelapa sawit (crude palm oil) dan karbon aktif. Peralatan yang digunakan dalam penelitian ini adalah erlenmeyer, beaker glass, pipet tetes, kertas saring Whatman No.1, gelas ukur, corong gelas, neraca digital, termometer, hot plate, motor listrik, impeller propeler, pengunci impeller, statif dan klem, stopwatch.

\section{Prosedur Penelitian. \\ Prosedur Kinetika Adsorpsi}

Sebagai langkah pertama, disiapkan karbon aktif dan minyak kelapa sawit dengan perbandingan (w/w) 1:5 dalam beaker glass. Kemudian campuran dipanaskan menggunakan hot plate pada suhu $60{ }^{\circ} \mathrm{C}$ dan dihomogenkan menggunakan motor listrik pada kecepatan konstan $120 \mathrm{rpm}$. Setelah itu, campuran diambil dengan interval waktu pengambilan 2 menit hingga mencapai waktu setimbang. Terakhir, sampel disaring dengan kertas saring Whatman No. 1.

\section{Prosedur Adsorpsi $\beta$-Karoten}

Proses adsorpsi dilakukan dalam beaker glass. dengan perbandingan (w/w) karbon aktif dan minyak kelapa sawit 1:3. Lalu campuran dipanaskan menggunakan hot plate pada suhu 40 ${ }^{\circ} \mathrm{C}$ dan dihomogenkan menggunakan motor listrik pada kecepatan konstan $120 \mathrm{rpm}$ selama 120 menit. Kemudian campuran disaring dengan kertas saring Whatman No. 1. Setelah disaring, dimasukkan kedalam botol plastik untuk dianalisa. 


\section{Analisis Produk}

Analisis terhadap $\beta$-karoten yang dihasilkan meliputi analisis konsentrasi akhir $\beta$-karoten dengan spektrofotometer UV-Vis dan analisa gugus $\beta$-karoten dengan FTIR.

\section{Hasil dan Pembahasan Kinetika Adsorpsi}

Pemodelan kinetika tidak hanya memungkinkan estimasi laju penjerapan tetapi juga mengarah pada mekanisme karakteristik reaksi yang sesuai [8]. Perhitungan dilakukan menggunakan pendekatan kinetika adsorpsi yaitu, orde satu Lagergen, orde dua dan difusi intra partikel. Persamaan umum model kinetika orde satu Lagergen dapat dilihat pada persamaan 1 .

$$
\frac{d q}{d t}=k_{1}\left(q_{e}-q_{t}\right)
$$

Kemudian persamaan tersebut diintegrasi menjadi persamaan 2 .

$$
\log \left(q_{e}-q_{t}\right)=\log q_{e}-\frac{k_{1}}{2,303}
$$

Dari persamaan 2, dibuat kurva t vs $\log \left(\mathrm{q}_{\mathrm{e}}-\mathrm{q}_{\mathrm{t}}\right)$. Kurva hasil model kinetika orde satu Lagergen dapat dilihat pada Gambar 2.

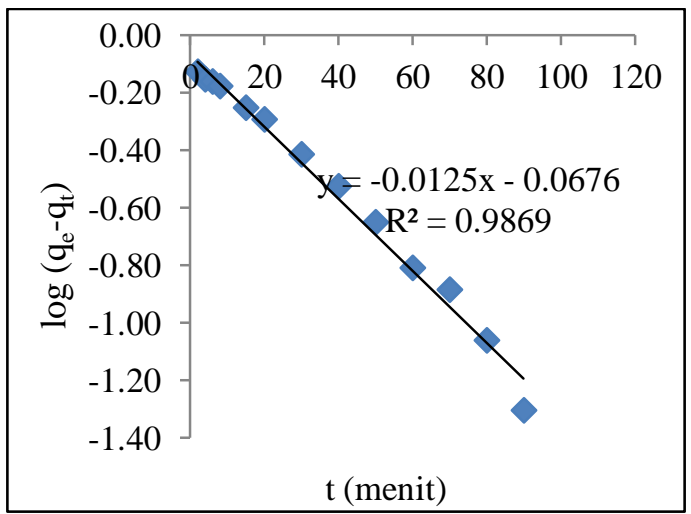

Gambar 2. Kinetika Orde Satu Lagergen

Untuk persamaan umum model kinetika orde dua ditunjukkan pada persamaan 3 .

$$
\frac{d q}{d t}=k_{2}\left(q_{e}-q_{t}\right)^{2}
$$

Kemudian persamaan 3 diintegrasi menjadi persamaan 4.

$$
\frac{t}{q_{t}}=\frac{1}{k_{2} q_{e}^{2}}+\frac{1}{q_{e}} t
$$

Dari persamaan 4, dibuat kurva t vs $\mathrm{t} / \mathrm{q}_{\mathrm{t}}$. Kurva untuk model kinetika orde dua disajikan pada Gmabar 3.
Persamaan umum model kinetika difusi intra partikel dapat diihat pada persamaan 5 .

$$
q_{t}=k_{3} t^{1 / 2}+C
$$

Persamaan 5 akan diintegrasi menjadi persamaan 6 .

$$
\log q_{t}=\log k_{3}+n \log t
$$

Dari persamaan 6, akan diplot kurva antara $\log \mathrm{t}$ Vs $\log \mathrm{q}_{\mathrm{t}}$. Hasil plot dapat dilihat pada Gambar 4.

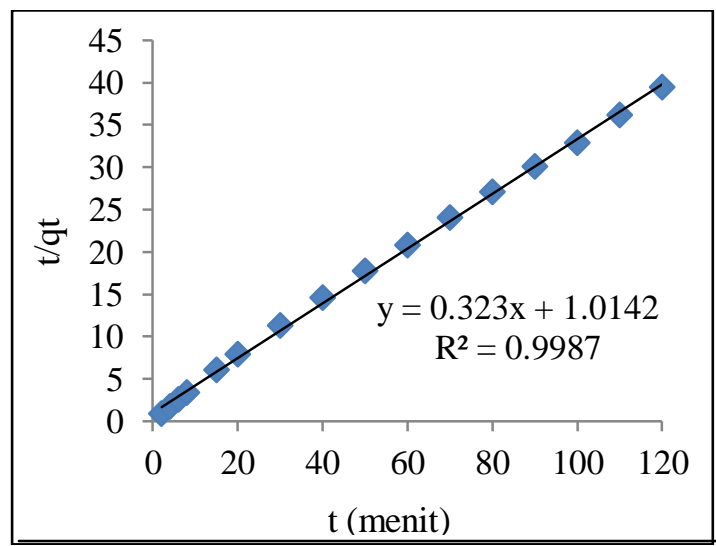

Gambar 3. Kinetika Orde Dua

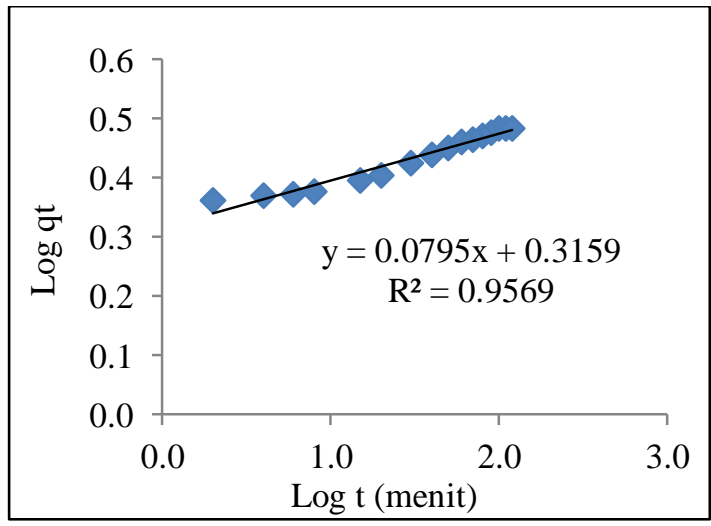

Gambar 4. Kinetika Difusi Intra Partikel

Penentuan model kinetika adsorpsi yang sesuai dapat ditinjau dari nilai $\mathrm{R}^{2}$ yang mendekati nilai 1 dari pada persamaan kinetika adsorpsi [12]. Dari grafik pada Gambar 2, 3 dan 4 dapat dilihat bahwa persamaan kinetika dengan nilai $\mathrm{R}^{2}$ mendekati 1 adalah pada persamaan kinetika orde dua : $y=0,323 x+1,0142$ dengan nilai $\mathrm{R}^{2}$ sebesar 0,9987 . Hal ini menunjukkan bahwa model kinetika yang sesuai untuk proses adsorpsi $\beta$-karoten menggunakan karbon aktif adalah model kinetika reaksi orde dua. 


\section{Studi Isoterm Adsorpsi}

Model isoterm adsorpsi ditentukan untuk mengetahui proses distribusi antara fase cair dan fase adsorben padat yang merupakan ukuran dari posisi keseimbangan dalam proses adsorpsi dan dapat dinyatakan dengan model isoterm Langmuir dan Freundlich.

\section{Isoterm Langmuir}

Persamaan isoterm Langmuir yang digunakan ditunjukkan pada Persamaan 7.

$$
\frac{C e}{q e}=\frac{1}{K_{L} q_{m}}+\left(\frac{1}{q_{m}}\right) C_{e}
$$

Dimana $\mathrm{q}_{\mathrm{e}}(\mathrm{mg} / \mathrm{kg})$ adalah jumlah adsorbat per satuan massa adsorben, $\mathrm{C}_{\mathrm{e}}(\mathrm{mg} / \mathrm{kg})$ adalah konsentrasi kesetimbangan adsorbat, $\mathrm{q}_{\mathrm{m}}(\mathrm{mg} / \mathrm{kg})$, dan $\mathrm{K}_{\mathrm{L}}(\mathrm{mg} / \mathrm{kg})$ adalah konstanta Langmuir yang terkait dengan kapasitas adsorpsi dan tingkat adsorpsi. Diplot kurva Ce vs qe dari data-data yang diperoleh dari hasil perhitungan. Kurva isoterm Langmuir dapat dilihat pada Gambar 5.

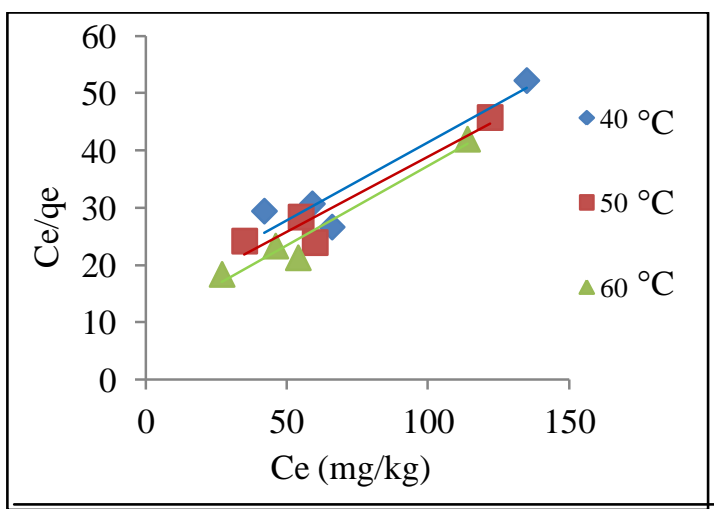

Gambar 5. Kurva Isoterm Langmuir untuk Adsorpsi $\beta$-Karoten

\section{Isoterm Freundlich}

Persamaan yang digunakan untuk isoterm Freundlich ditunjukkan pada Persamaaan 8.

$$
\log q_{e}=\log K_{F}+\frac{1}{n} \log C_{e}
$$

$\mathrm{q}_{\mathrm{e}}(\mathrm{mg} / \mathrm{kg})$ adalah jumlah adsorbat per satuan massa adsorben, $\mathrm{C}_{\mathrm{e}}(\mathrm{mg} / \mathrm{kg})$ adalah konsentrasi kesetimbangan adsorbat, dan $\mathrm{K}_{\mathrm{F}}$ $\left((\mathrm{mg} / \mathrm{kg}) .(\mathrm{mg} / \mathrm{kg})^{-\mathrm{n}}\right) \quad$ didefinisikan sebagai kapasitas adsorpsi adsorben dan konstanta Freundlich. Diplot kurva Log Ce Vs Log $\mathrm{q}_{\mathrm{e}}$, hasil plot ditunjukkan pada Gambar 6 .

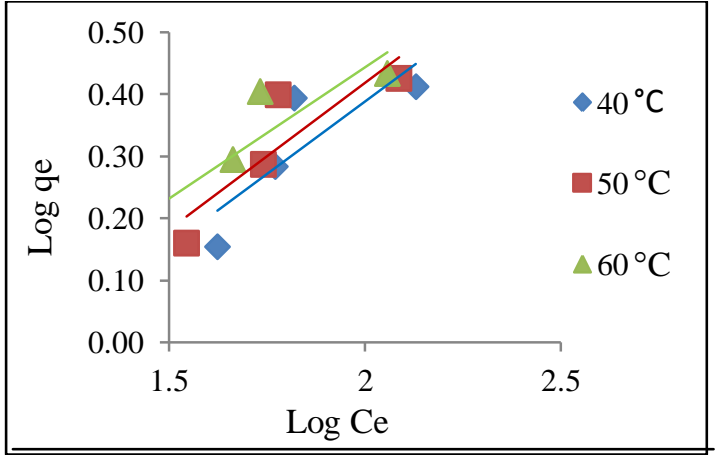

Gambar 6. Kurva Isoterm Freundlich untuk Adsorpsi $\beta$-Karoten

Model isoterm Freundlich untuk penjerapan $\beta$ karoten pada temperatur $60{ }^{\circ} \mathrm{C}$ menghasilkan nilai $\mathrm{R}^{2}$ sebesar 0,8184 . Pada temperatur yang sama, diperoleh kesesuaian data yang lebih baik untuk model isoterm Langmuir dengan nilai $\mathrm{R}^{2}$ yakni sebesai 0,9590. Nilai $\mathrm{R}^{2}$ yang paling mendekati nilai 1 adalah model isoterm Langmuir. Proses adsorpsi yang mengikuti model isoterm Langmuir melibatkan asumsi bahwa permukaan adsorben adalah homogen [10], artinya pada setiap molekul $\beta$-karoten yang terjerap oleh karbon aktif memiliki entalpi dan energi aktivasi yang sama pada setiap serapan (semua situs memiliki afinitas yang sama untuk adsorbat) [5,14]. Model Langmuir juga didasarkan pada asumsi hanya terdapat satu lapisan permukaan (monolayer) yang teradsorpsi oleh karbon aktif [14].

Karakteristik dari isoterm Langmuir dapat dinyatakan dengan parameter kesetimbangan $\left(\mathrm{R}_{\mathrm{L}}\right)$. Persamaann untuk parameter kesetimbangan disajikan pada Persamaan 9.

$$
R_{L}=\frac{1}{1+K_{l} C_{o}}
$$

dimana $\mathrm{K}_{\mathrm{L}}$ adalah konstanta Langmuir dan $\mathrm{C}_{\mathrm{o}}$ adalah konsentrasi $\beta$-karoten yang terbesar ( $\mathrm{mg} / \mathrm{l})$. Nilai $\mathrm{R}_{\mathrm{L}}$ menunjukkan karakteristik jenis isotherm, yakni baik $\left(0<\mathrm{R}_{\mathrm{L}}<1\right)$, kurang baik $\left(\mathrm{R}_{\mathrm{L}}>1\right)$, liniar $\left(\mathrm{R}_{\mathrm{L}}=1\right)$, dan ireversibel $\left(\mathrm{R}_{\mathrm{L}}=0\right)$ [3]. Dari hasil diperoleh nilai $\mathrm{R}_{\mathrm{L}}$ sebesar 0,5566. Dengan begitu dapat dinyatakan bahwa jenis isoterm termasuk dalam kategori baik.

\section{Termodinamika Adsorpsi}

Dalam setiap proses adsorpsi, pertimbangan energi dan entropi harus diperhitungkan untuk menentukan bahwa proses yang berlangsung secara spontan. Nilai-nilai termodinamika adalah parameter indikator sebenarnya untuk aplikasi praktis dari proses [20]. Persamaan yang digunakan untuk melakukan perhitungan sifat Termodinamika adsorpsi $\quad \beta$-Karoten dapat dilihat pada persamaan 10 dan 11 . 


$$
\Delta G=-R T \ln K_{a d s}
$$

$\mathrm{R}$ adalah konstanta gas ideal $(8,314 \mathrm{~J} / \mathrm{mol} \mathrm{K}), \mathrm{T}$ (K) adalah temperatur, dan $\mathrm{K}_{\mathrm{ads}}$ adalah konstanta dari isoterm Langmuir $\left(\mathrm{K}_{\mathrm{L}}\right)$.

$$
\ln K_{a d s}=\frac{\Delta S}{R}-\frac{\Delta H}{R} \frac{1}{T}
$$

Plot kurva antara $1 / \mathrm{T}$ vs $\ln \mathrm{Ka}_{\mathrm{ds}}$ diperlihatkan pada Gambar 7.

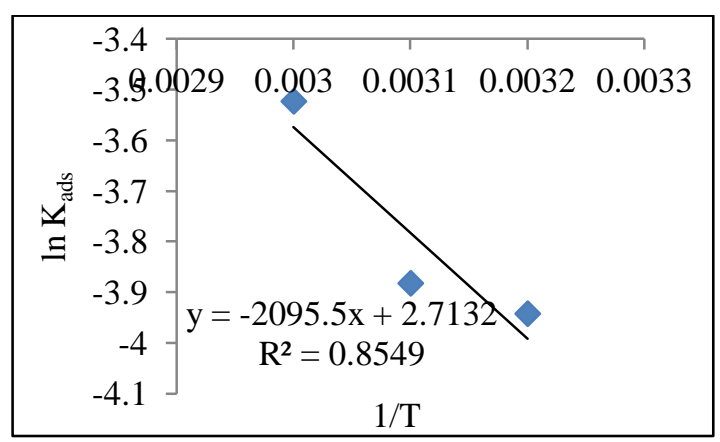

Gambar 7. Termodinamika Adsorpsi

Untuk mencari $\Delta \mathrm{G}, \Delta \mathrm{H}$ dan $\Delta \mathrm{S}$ menggunakan Persamaan 10 dan 11, diperoleh nilai masingmasing parameter yang ditunjukkan pada Tabel 3 .

Tabel 3. Hasil Termodinamika Adsorpsi

\begin{tabular}{|c|c|c|c|}
\hline $\mathbf{T}$ & $\boldsymbol{\Delta} \mathbf{G}(\mathbf{J} / \mathbf{m o l})$ & $\begin{array}{c}\boldsymbol{\Delta} \mathbf{S} \\
(\mathbf{K})\end{array}$ & \multirow{2}{*}{$\boldsymbol{\Delta} \mathbf{H} \mathbf{~ ( J / \mathbf { m o l } \mathbf { K } )}$} \\
\cline { 1 - 2 } 313 & $-24.482,4845$ & \multirow{2}{*}{22,5575} & $-17.421,9870$ \\
\cline { 1 - 2 } 323 & $-24.708,0595$ & & \\
\cline { 1 - 2 } 333 & $-24.933,6345$ & & \\
\hline
\end{tabular}

Dari Tabel 3, $\Delta \mathrm{G}$ bernilai negatif. Ini mengidentifikasikan bahwa proses adsorpsi $\beta$ karoten menggunakan karbon aktif adalah baik dan spontan. $\Delta \mathrm{G}$ semakin meningkat dengan meningkatnya temperatur. Disamping itu, nilai $\Delta \mathrm{H}$ yang bernilai negatif menunjukkan bahwa proses adsorpsi berjalan secara eksotermis. Proses eksotermis mengidentifikasikan bahwa proses yang terjadi dalam penjerapan $\beta$-karoten adalah adsorpsi fisika [4]. Nilai $\Delta \mathrm{S}$ yang positif mengidentifikasikan bahwa adsorben jika berada pada keadaan padat/cair selama proses adsorpsi, maka tidak sempurna (cairan tidak terjerap secara sempurna).

\section{Efek Temperatur}

Temperatur sangat berpengaruh dalam proses adsorpsi. Dari termodinamika adsorpsi, telah diketahui bahwa proses adsorpsi ini berjalan secara eksotermis. Pengaruh temperatur pada berbagai rasio massa karbon aktif : CPO terhadap persentase adsorpsi yang ditunjukkan pada Gambar 8.

Pada Gambar 8, dapat dilihat bahwa proses penjerapan meningkat ketika temperatur meningkat karena adanya peningkatan mobilitas $\beta$-karoten dalam larutan. Adsorpsi fisika biasanya berlangsung pada temperatur yang lebih rendah dari $100{ }^{\circ} \mathrm{C}$ dan adsorpsi kimia untuk temperatur yang lebih tinggi dari $100{ }^{\circ} \mathrm{C}$ [9]. Meskipun temperatur yang tinggi dapat meningkatkan proses penjerapan, namun suhu tidak boleh dinaikkan tanpa batasan karena dapat merusak $\beta$ karoten [5].

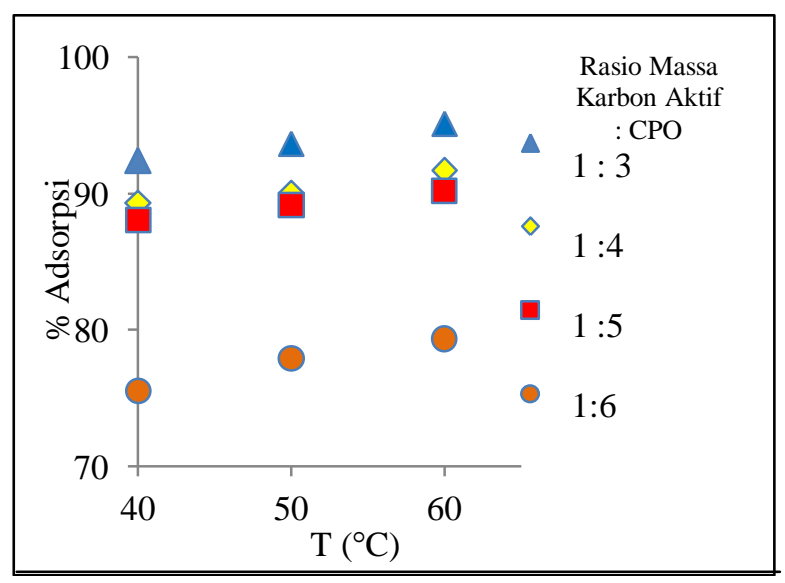

Gambar 8. Pengaruh Temperatur Terhadap Persentase Adsorpsi

\section{Kesimpulan}

Semakin besar suhu adsorpsi maka persentase adsorpsi semakin meningkat. Nilai persentase adsorpsi maksimum sebesar 95,108\% diperoleh pada perbandingan CPO : karbon aktif (w/w) $1: 3$ dan $\mathrm{T}=60{ }^{\circ} \mathrm{C}$. Persamaan model isoterm yang mewakili penjerapan $\beta$-karoten adalah isoterm Langmuir dengan nilai $\mathrm{R}^{2}$ sebesar 0,959 pada $\mathrm{T}=$ $60{ }^{\circ} \mathrm{C}$. Persamaan model kinetika yang mewakili penjerapan $\beta$-karoten adalah kinetika orde dua dengan nilai $\mathrm{R}^{2}$ sebesar 0,998. Data termodinamika adsorpsi yang diperoleh nilai-nilai $\Delta \mathrm{G}$ pada masing-masing suhu 40,50 dan $60{ }^{\circ} \mathrm{C}$ sebesar -24.482,484, -24.708,059 dan -24.933,634 $\mathrm{J} / \mathrm{mol}$. Nilai $\Delta \mathrm{S}$ sebesar $22,557 \mathrm{~J} / \mathrm{mol} \mathrm{K}$ dan nilai $\Delta \mathrm{H}$ sebesar $-17.421,987 \mathrm{~J} / \mathrm{mol}$.

\section{Daftar Pustaka}

[1] A. Buekens, " Adsorbents and Adsorption Proceses for Poluution Control," Pollution Control Technologies, Vol. 2, 2001.

[2] A.L, Ahmad, C.Y, Chan, S.R, Abd Shukor, Dan M. D, Mashitah , "Adsorption Kinetics and Thermodynamics of B-Carotene on Silica - Based Adsorbent," "Chemical Engineering Journal, 148, 378-384, 2009. 
[3] Alok Mittal, Lisha Kurup, And Jyoti Mittal. "Freundlich and Langmuir Adsorption Isotherms And Kinetics for The Removal of Tartrazine From Aqueous Solutions Using Hen Feathers." Elsevier Journal of Hazardous Materials 146, 243-248, 2007.

[4] Andhika, Akbar. "Optimasi Ekstraksi Spent Bleaching Earth Dalam Recovery Minyak Sawit," Skripsi, Program Sarjana Fakultas Teknik UI, Depok, Hal 29-30, 2012.

[5] B.H. Hameed, A.T.M. Din, and A.L. Ahmad. "Adsorption of Methylene Blue Onto Bamboo-Based Activated Carbon: Kinetics and Equilibrium Studies." Elsevier Journal of Hazardous Materials 141, 819-825, 2007.

[6] B. Nagendran, U.R, Unnithan, Y.M, Choo, and Kalyana, Sundram, "Characteristics of Red Palm Oil, A Carotene- and Vitamin ERich Refined Oil For Food Uses," Food and Nutrition Bulletin, Vol. 21, No. 2, 2000.

[7] E. Sabah, M. Cinar, and M.S, Celik "Decolorization of Vegetable Oils: Adsorption Mechanism of B-Carotene on Acid-Activated Sepiolite," Food Chemistry, Vol. 100,1661-1668, 2007.

[8] Hui Qiu, Lu Lv, Bing-Cai Pan, Qing-Jian Zhang, Wei-Ming Zhang, and Quan-Xing Zhang. " Critical Review In Adsorption Kinetic Models," Journal of Zhejiang University Science A, 10(5):716-724, 2009.

[9] Joshi, Sahira. Pokharel, Bhadra Prasad. "Preparation and Characterization of Activated Carbon From Lapsi (Choerospondias Axillaris) Seed Stone By Chemical Activation With Potassium Hydroxide." Journal of The Institute of Engineering, Vol. 9, No. 1, Pp. 79-88.

[10] K.Y. Foo, B.H. Hameed. "Insights Into The Modeling of Adsorption Isotherm Systems." Elsevier Chemical Engineering Journal 156, 2-10, 2010.

[11] Malaysian Standard, "Palm Oil Specification (Second Revision)," Department of Standards Malaysia, 2007.

[12] Maria Angela N S, Arenst Andreas, dan Aditya Putranto, "Sintesis Karbon Aktif Dari Kulit Salak Dengan Aktivasi $\mathrm{H}_{3} \mathrm{PO}_{4}$ Sebagai Adsorben Larutan Zat Warna Metilen Biru." Prosiding Seminar Nasional Teknik Kimia Kejuangan. Issn 1693-4393 Pengembangan Teknologi Kimia Untuk Pengolahan Sumber Daya Alam Indonesia, Yogyakarta, 18 Maret 2015.

[13] Merckmillipore.'Material Safety Data Sheet Arang Aktif', 2015.

[14] Murni Handayani, dan Eko Sulistiyono. "Uji Persamaan Langmuir dan Freundlich Pada Penyerapan Limbah Chrom (Vi) Oleh Zeolit." Prosiding Seminar Nasional Sains dan Teknologi Nuklir Ptnbr - Batan Bandung, 3 Juni 2009.

[15] Nwankwere E.T, Nwadiogbu, J.O, Yilleng, M.T, and Eze, K.A, "Kinetic Investigation of The Adsorptive Removal Of B-Carotene," Advances In Applied Science Research, , 3 (2):1122-1125, 2012.

[16] Otu, Okogeri, Blessing, Okoro, "Storage Stability And Sensory Attributes of Crude Palm Oil Adulterated With Red Dye," European Journal of Agriculture And Forestry Research, Vol.2, No.1, Pp.10-17, March 2014.

[17] Pradhan, Subhashree. "Production and Characterization of Activated Carbon Produced From A Suitable Industrial Sludge". Department of Chemical Engineering National Institute of Technology Rourkela, 2007.

[18] R.A. Latip, B.S, Baharin, Y.B, Che Man, And R.A, Rahman, "Effect of Adsorption And Solvent Extraction Process On The Percentage of Carotene Extracted From Crude Palm Oil," Department of Food Technology, Faculty of Food Science And Biotechnology, Universiti Putra Malaysia, 2001.

[19] Simone M. Silva, Klicia A, Sampaio , Roberta, Ceriani, Roland, Verhé, Christian, Stevens, Wim De, Greyt , and Antonio, J.A. Meirelles "Adsorption of Carotenes and Phosphorus From Palm Oil Onto Acid Activated Bleaching Earth : Equilibirium, Kinetics And Themodynamic," Journal of Food Engineering, Vol. 118, 341 - 349, 2013.

[20] S. M. Yakout And E. Elsherif. "Batch Kinetics, Isotherm and Thermodynamic Studies of Adsorption of Strontium From Aqueous Solutions Onto Low Cost RiceStraw Based Carbons." Applied Science Innovations Pvt. Ltd., India. 144 - 153, 2010.

[22] Siti, Hamidah Mohd Setapar, Asma, Khatoon, Akil, Mohd, Azizi Che Yunus, Dan Muhammad Abbas Ahmad Zaini, "Use of Supercritical $\mathrm{CO}_{2}$ and R134a As Solvent For Extraction of B-Carotene and ATocopherols From Crude Palm Oil," Asian Journal of Chemistry; Vol. 26, No. 18, 5911-5916, 2014. 